DOI: $10.15838 / \mathrm{esc} / 2015.2 .38 .9$

UDC 316.44, LBC 60.5

(C) Pasovets Yu.M.

\title{
Risks of poverty in the modern Russian conditions*
}

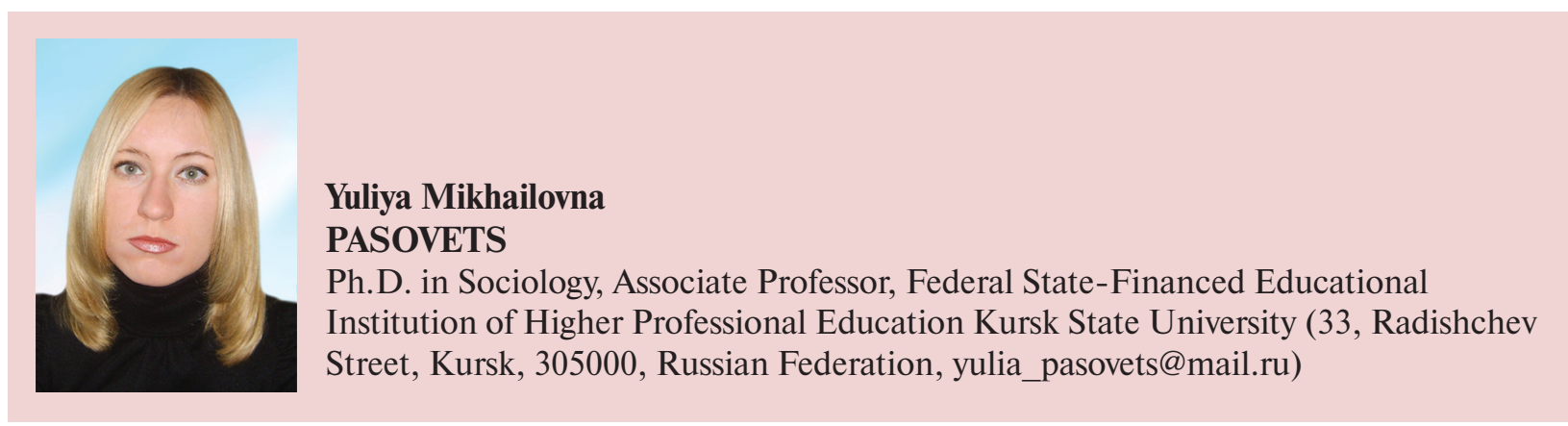

Abstract. Poverty acts as an indicator of insufficiency and deficit of economic resources of the population; its boundaries serve as a demarcation line between people's adaptation to social and economic changes and their maladjustment. The construction of a socio-demographic portrait of the poor, reflecting its recent dynamics and the current state helps identify the key risks of poverty and their stability in the modern Russian conditions. It is difficult for certain social categories to adapt. The specificity of socio-economic differentiation of the population in the modern Russian society is connected with the persistence of the stratification profile defined by the unequal distribution of money income among the population groups during the period of reforms. Raised standards of living of most population in the 2000s led to the drastic reduction in absolute poverty, defined by the boundaries of income below the subsistence minimum. However, nowadays, according to the objective indicators of the income amount, the tenth part of the Russians is considered as the poor. The population's income is still insufficient; it testifies the presence of poverty risks for some categories of the population in the modern Russian conditions. The analysis of the dynamics and state of the objective sources of poverty shows that the high poverty rates are observed in small towns (with the population being equal to 50-100 thousand inhabitants and up to 50 thousand people) and rural settlements and refer to children and youth under 30 , the unemployed and economically inactive population. Besides, the working poor employed in industries get low wages.

Key words: poverty, risk of poverty, the unemployed, the working poor, socio-economic adaptation, social transformation.

* The work is prepared in the framework of the research project "Adaptive potential of the population in the conditions of Russian society transformation” supported by the Russian Foundation for Humanities grant No. 13-33-01208 a2. 
The specific character of life in the modern Russian society is connected with the need to promote social adaptation to economic and institutional changes caused by the process of transforming social institutions and social structure in general.

The dynamics and instability of the market economy has a key impact on the labor and employment sphere, and on the level and quality of life; that is why the socio-economic adaptation of the population becomes very important. In these conditions the subjects of adaptation (individuals, social groups or communities) should use available economic resources in order to satisfy their own demands and interests. The volume of these resources ensures a different level of adaptability to changing conditions of life. In this situation it is necessary to consider poverty as a measure of insufficiency and lack of economic resources of a certain part of the population, which boundaries serve as a demarcation line between its adaptation and maladjustment to socio-economic changes. In this respect, attention should be drawn not only to the traditional categories of the poor, but also to the categories of the poor such as the unemployed and the working poor, belonging to the economically active population.

In the first period of the Russian society transformation (the 1990s) the socioeconomic transformation led to the sharp increase in property differentiation and the significant rise of poverty.
At this time, the drop in the standard of living of the population was reflected in the decrease in the level of income and consumption, the depreciation of savings, the growth of unemployment, the increase in debt by all types of payments and other negative manifestations.

Since 2000 the socio-economic situation in the country had been gradually improving: the population's income had been growing, the unemployment and poverty had been reducing, etc. These trends presuppose the occurrence of the second stage of the Russian society structural transformation associated with social stabilization.

However, the onset of the 2008 economic crisis had adverse consequences for the dynamics of employment, the level and quality of life of the population: the average wages of employees of organizations and enterprises decreased, the amount of arrears increased, etc. This resulted in certain difficulties in the population's adaptation to changing social conditions. However, they were not so deep as in 1998, that is why the trend to reduce poverty remained.

Despite the significant decrease in poverty in the 2000s, in the Russian society still there is a problem to alleviate poverty to the level, which is natural for the market economy, and reduce poverty risks for certain categories of the population. This problem is among the most significant for the modern Russian society development. A.A. Shabunova and M.A Lastochkina note that nowadays social inequality and 
low living standards are one of the main obstacles to socio-cultural modernization of the country ${ }^{1}$. Their overcoming helps reach higher standards and quality of life of the population.

Moreover, today the problem becomes particularly acute, as once again the Russian society faces the market economy instability, leading to the deterioration of the economic situation in the country since the second half of 2014 and the onset of the economic crisis, reflected in increased inflation, reduced real income of the population, etc. In these conditions there are poverty risks for the total population and certain categories of citizens.

In this regard it is important to monitor the poverty level, profile, structure and risks and use the scientific research results in practice of social management. In the new socio-economic circumstances it is critical to identify the main sources of poverty, their objective or subjective nature, sustainability and, consequently, key poverty risks. The identification and characterization of poverty risks in the modern Russian conditions will contribute to the scientific understanding of the socioeconomic situation in the country and the definition of the specific measures to reduce poverty and boost the efficiency of social policy. These circumstances determine the relevance of the study.

1 Shabunova A.A., Lastochkina M.A. Preodolenie sotsial'nogo neravenstva kak impul's k sotsiokul'turnoi modernizatsii [Overcoming Social Inequality as an Impetus to Socio-Cultural Modernization]. Ekonomicheskie $i$ sotsial'nye peremeny: fakty, tendentsii, prognoz [Economic and Social Changes: Facts, Trends, Forecast], 2014, no. 3 (33), pp. 69.
The object of the research is poverty of the population, and the subject is poverty risks of the Russians in modern conditions. The work is aimed at identifying and characterizing key risks of poverty in today's Russia. It sets the tasks to determine the theoretical and methodological foundations for the research in poverty of the population, to describe the sociodemographic composition of the poor population, its dynamics in recent years and consider the main risks of poverty related to their social and demographic characteristics.

The theoretical and methodological basis of the study is presented in the absolute concept of poverty, according to which poverty is characterized by the minimum list of needs and resources to meet them. This understanding of poverty allows us to consider it as an indicator of scarce economic resources and socioeconomic maladjustment of the population. The state statistics data on the size and composition of the poor population in Russia in 2000-2013 are the empirical base of the research. It determines the use of the statistical data analysis as the main method of research.

It should be noted that to date socioeconomic knowledge has not developed a clear understanding of essential characteristics of poverty and an unambiguous approach to its measurement, ensuring the conformity of the procedure to this phenomenon. In this regard, it is necessary to clarify the nature of poverty, the main 
approaches to its understanding and the key factors influencing its nature and characteristics.

The multidimensionality of poverty as a social phenomenon leads to the ambiguity of this concept definition in social science. In our opinion, various interpretations of poverty can be reduced to two approaches.

The first approach assumes a narrow understanding of the term, as it focuses on one poverty indicator - a low income (property) status, limiting the consumption of its owners. According to this approach, people are considered to be "poor if their welfare is below a certain level" ${ }^{2}$. The approach is widespread in sociology, economics, social geography and other social sciences.

The second approach links the category of poverty to social exclusion. In this view, poverty is characterized by the low-income of households or individuals, the limited possibilities on the labor market, in health care and education and the insufficient protection from various socio-economic shocks ${ }^{3}$, etc. This notion of poverty is new for the socio-economic knowledge.

Regardless of the width of poverty understanding there are two main methodological approaches to its measurement: objective and subjective.

2 Cited by: Litvinov V.A. Prozhitochnyi minimum: istoriya, metodika, analiz [Minimum Wage: History, Method, Analysis]. Moscow: KomKniga, 2006, p. 202.

3 Zubarevich N.V. Sotsial'noe razvitie regionov Rossii: problemy $i$ tendentsii perekhodnogo perioda [Social Development of Russian Regions: Problems and Tendencies of the Transition Period]. Second edition. Moscow: Editorial URSS, 2005, p. 161.
The objective approach to poverty is based on the analysis of statistical indicators of living standards and the identification of the poverty line (that is, a threshold of minimum cash income/expenses and consumption of the population). It is presented by the concepts of relative and absolute poverty.

In terms of the absolute concept of poverty, the poverty line is determined by the inadequacy of their resources to meet the minimum requirements. The absolute poverty line presupposes that the minimum requirements are not satisfied due to low income.

The concept of absolute poverty suggests that the government maintains a minimum set of goods and services, most necessary for consumption; the cost of this set is a threshold or a poverty line. In turn, the statistical agencies monitor resources of the households in order to estimate the proportion of the poor population ${ }^{4}$.

The absolute concept that emerged in the 1900s in the context of ideas about the minimum wage was developed in the works of Ch. Booth, V. Rowntree, M. Orshansky, etc. Nowadays it is widely used in many countries (Russia, the majority of CIS countries, the USA, etc.) to determine the national poverty line, required for the social policy implementation.

${ }^{4}$ Ovcharova L.N. Teoreticheskie i prakticheskie podkhody $k$ otsenke urovnya, profilya i faktorov bednosti: rossiiskii i mezhdunarodnyi opyt [Theoretical and Practical Approaches to the Assessment of the Level, Profile and Determinants of Poverty: Russian and International Experience]. Moscow: M-Studio, 2009, p. 14. 
The main directions for the application of the absolute poverty level in social management are to monitor the poverty rate and identify the conditions for the poor to participate in the targeted programs. To date this poverty line can not be applied to regulate the minimum wage, as, for example, in the USA, where the minimum wage has exceeded this limit. However, the absolute national poverty lines are not used in cross-national comparisons, as in this case they become relative. For it the absolute international poverty line of the World Bank is applied ${ }^{5}$.

In the Russian Federation the absolute poverty line is fixed by the value of the subsistence minimum. According to the Federal Law "On the subsistence minimum in the Russian Federation" of October 24, 1997 (with amendments), the subsistence minimum is understood as a value of the consumer basket, mandatory fees and charges. The consumer basket is defined as a minimum set of food and non-food goods and services required to maintain people's health and life activity, whose value is determined in relation to the cost of the minimum set of food products. The subsistence minimum performs the function to assess the standard of living in the Russian Federation when elaborating and implementing social policies and

5 Partisipatornyi podkhod $v$ povyshenii kachestva zhizni naseleniya: monografiya [Participatory Approach to Improving the Quality of Life of the Population: Monograph]. Under general editorship of N.M. Rimashevskaya, N.N. Ivashinenko. Nizhny Novgorod Moscow: Izd-vo Nizhegorodskogo gosuniversiteta, 2013, p. 122. federal social programs, determining the minimum monthly wage and the size of scholarships, grants and other social payments set at the federal level ${ }^{6}$.

The advantages of using the absolute poverty line are determined by the ability to monitor changes in the scale and profile of poverty occurring over time on the basis of statistical data. The elaborated method, the standardized technique, the systematic measurement of indicators and the possibility of unambiguous interpretation of the survey results make it possible to overcome the differences in the poverty estimates characteristic of other approaches. The shortfalls to be criticized are the following: the need to adjust the minimum goods and services basket when the minimum consumption standard expands, the underestimation of hidden income and non-monetary revenue to the household budget and the necessity to ensure the representativeness of the household surveys results, etc.

In terms of the objective approach in the relative poverty concept, the poverty line is associated with the level of the population's welfare prevailing in a particular country (region). The relative poverty line is fixed in relation to some measure of welfare for the population, in general, and is determined by the lack of resources to maintain consumption at a level accepted in a given society.

6 Federal'nyi zakon "O prozhitochnom minimume v Rossiiskoi Federatsii": ot 24.10.1997 g. (s izm.) [Federal Law "On Subsistence Minimum in the Russian Federation of October 24, 1997 (with Amendments)]. Konsul'tantPlyus [Reference-Legal System KonsultantPlus]. 
The relative poverty concept as an alternative to the absolute one was elaborated in the postwar period, have been actively developing since the 1970s. Its ideas are reflected in the works of P. Townsend, A. Atkinson, A. Sen, J. Mack, S. Lansley, etc. Nowadays there are two versions of this approach: "deprivation" and "median"7. According to the first version, first mentioned by $\mathrm{P}$. Townsend, the deprivation threshold, below which it becomes impos-sible to maintain a common standard of living, is defined by the set of deprivations, expressed in the "natural form".

The expert and sociological methods are used for identifying the prevailing standard of living and the deviations from it. The list of deprivations and the presence or absence of these deprivations are identified. The poverty line is considered as a certain concentration of these deprivations.

The second version of the approach presupposes that the deprivation threshold is calculated according to the ratio of average incomes of the respondents and the medians of their indicators. The complexity to realize the deprivation approach has led to a wider application of the median approach, considering the poverty line at the level of $40-60 \%$ of the median income of the population.

In the European countries the research in poverty under the relative approach is

7 Slobodenyuk E.D., Tikhonova N.E. Evristicheskie vozmozhnosti absolyutnogo i otnositel'nogo podkhodov $\mathrm{k}$ izucheniyu bednosti $\mathrm{v}$ rossiiskikh usloviyakh [Heuristic Possibilities of Absolute and Relative Approaches to the Study of Poverty in Russia]. Sotsiologiya: $4 M$ [Sociology: 4M], 2011, no. 33, p. 7. conducted regularly and used for the compilation of national poverty lines. Russia does not conduct statistical monitoring on deprivation of the population; however, it is studied by L.N. Ovcharova, N.E. Tikhonova, A.Yu. Shevyakov and others ${ }^{8}$.

The approach advantages are the following: control of changes in the minimum consumption standard adopted in a particular society, accessibility of goods and services, monitoring of inequality in the society, socio-demographic composition of the poor, etc. The letter is significant for the provision of targeted social assistance. In the course of such a measurement it is difficult to make a list of deprivations and indicators of the poverty line due to the possibility of irrational consumption.

The subjective approach to measure poverty is based on the population's assessments of their financial situation and characteristics of poverty. In the framework of this approach the poverty line reflects people' estimates of the minimum living standard acceptable in a particular society. The survey is a key measuring tool. The subjective poverty concept, developed by the economists and statisticians of Leiden University in the Netherlands in the 1970s, is widespread in sociology today. It is a theoretical and methodological basis of research in the people's opinions about poverty and its indicators.

8 Ovcharova L.N. Teoreticheskie i prakticheskie podkhody $k$ otsenke urovnya, profilya i faktorov bednosti: rossiiskii i mezhdunarodnyi opyt [Theoretical and Practical Approaches to the Assessment of the Level, Profile and Determinants of Poverty: Russian and International Experience]. Moscow: M-Studio, 2009. Pp. 7-19. 
There are advantages of this approach, such as the possibility to identify and consider the estimations of the minimum amount of resources required to meet vital needs of an individual, the views of the poor about the constraints that affect their quality of life, as well as the dynamics of these representations under the influence of socio-economic and socio-cultural changes.

In this respect, the subjective poverty line should match and complement the poverty line, which is set in terms of the objective approach with due regard for statistical indicators.

Under the subjective approach, based on the results of representative surveys of public opinion, the monetary and nonmonetary poverty lines are constructed. The monetary poverty line includes people's responses about the minimum income, required for a household, non-monetary self-assessments of their financial situation.

There are examples of systematic implementation of the monetary method to construct subjective poverty lines, such as surveys of the Gallup Institute in the USA, Eurobarometer of Public Opinion in the EU, etc. In Russia the non-monetary method is more widespread; it involves the construction of a specific stratification scale.

So, the stratification scale is used in the population surveys carried out by the sample program and the method "Sociocultural portrait of a Russian region" in the framework of the program "Issues of socio-cultural evolution of Russia and

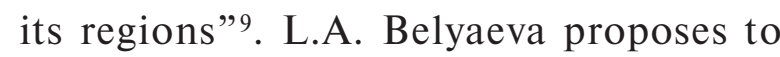
determine the respondents' status in terms of consumption, when they refer themselves (their family) to one of six conditionally identified strata: "the beggars" (answer "There is not enough money for everyday expenses"), "the poor" ("The whole salary is spent on everyday expenses"), "the disadvantaged" ("There is enough money for everyday expenses, but it is difficult to buy clothes"), "the well-to-do" ("There is enough money, but to buy expensive items we have to borrow money"), "the wealthy" ("There is enough money practically for everything, but to buy a flat or a summer cottage is difficult"), "the rich" ("We can afford everything" $)^{10}$.

According to this scale, two groups with low incomes and limited consumption can be considered as the poor: "the beggars" and "the poor"11. The results of foreign and Russian studies show that the subjective poverty line is higher than the official

9 Lapin N.I., Belyaeva L.A. Programma i tipovoi instrumentarii "Sotsiokul'turnyi portret regiona Rossii" (Modifikatsiya - 2010) [Program and Standard Tool "Socio-Cultural Portrait of the Region of Russia" (Modification - 2010]. Ros. akad. nauk, In-t filosofii. Moscow: IFRAN, 2010. $111 \mathrm{p}$.

${ }^{10}$ Belyaeva L.A. Sotsial'naya stratifikatsiya i bednost' v regionakh Rossii (k sostavleniyu sotsiokul'turnogo portreta regionov) [Social Stratification and Poverty in the Regions of Russia (to Build a Socio-Cultural Portrait of the Regions)]. Sotsiologicheskie issledovaniya [Sociological Studies], 2006, no. 9, pp. 52-63.

${ }^{11}$ Pasovets Yu.M. Sotsial'nye resursy i ogranicheniya razvitiya regiona $v$ kontekste obshcherossiiskikh izmenenii [Social Resources and Limitations of the Region's Development in the Context of Nationwide Changes]. Kursk: Kurskii gos. un-t., 2010, p. 139. 
one ${ }^{12}$ and the proportion of the poor by the stratification scale, constructed by the level of consumption is higher than the level of absolute poverty ${ }^{13}$.

Limitations of poverty measurement in the framework of the subjective approach are largely related to people's ambiguous understanding and interpretation of the phenomenon of poverty. One individual can interpret poverty as a low income, providing a level of consumption below the poverty line; another respondent - as a lack of freedom of action and choice, when in the economic context this freedom is identified with the fairly high standard of goods and services consumption and the need to ensure appropriate means. The practice to conduct population surveys indicates that the latter interpretation of poverty is found among the well-to-do who can subjectively consider themselves as the poor. At the same time, some people who are objectively poor do not consider themselves as such, because they associate poverty with income and consumption below their own in order to compensate their psychological discomfort from the awareness of their low material status. Having analyzed the 2013 nationwide

${ }^{12}$ Bednost' $i$ bednye v sovremennoi Rossii [Poverty and the Poor in Modern Russia]. Under editorship of M.K. Gorshkov i N.E. Tikhonova. Moscow: Ves' Mir, 2014, p. 21; Ovcharova L.N. Teoreticheskie i prakticheskie podkhody $k$ otsenke urovnya, profilya i faktorov bednosti: rossiiskii i mezhdunarodnyi opyt [Theoretical and Practical Approaches to the Assessment of the Level, Profile and Determinants of Poverty: Russian and International Experience]. Moscow: M-Studio, 2009, p. 44.

${ }_{13}$ Pasovets Yu.M. Imushchestvennaya stratifikatsiya naseleniya Rossii i ee regionov [Property Stratification of the Population of Russia and Its Regions]. Regionologiya [Regionology], 2011, vol. 77, no. 4, pp. 206-208. survey, N.E. Tikhonova makes a conclusion that "the poor Russians are now trying, rather, to embellish their position than to exaggerate their own poverty ...gradually in Russia it is becoming shameful to be poor" ${ }^{14}$. The sociological studies try to neutralize the limitations of subjective measures towards theoretical and empirical interpretation of the poverty concept and standardization of methodological tools.

The combination of different approaches result in more reliable estimates of poverty, as one measures and compares poverty by income, deprivation and subjective poverty. It is not common to apply this strategy in the practice of social management (for example, in the UK for the elimination of child poverty), although its practical significance encourages researchers to conduct research taking into account national peculiarities.

The analysis of theoretical and methodological approaches to understanding and measuring poverty shows that each of them has its advantages and shortfalls and, accordingly, the use of a specific approach is determined by the tasks to solve.

We believe that to build the sociodemographic portrait of the poor, reflecting its recent dynamics and current state, identify the key risks of poverty and their sustainability in the modern Russian conditions it is possible to use the absolute poverty concept, which also underlies

${ }^{14}$ Bednost' $i$ bednye v sovremennoi Rossii [Poverty and the Poor in Modern Russia]. Under editorship of M.K. Gorshkov i N.E. Tikhonova. Moscow: Ves' Mir, 2014, p. 34. 
Table 1. Proportion of the Russian population with money incomes below the subsistence minimum (in \% of the total population)

\begin{tabular}{|l|l|l|l|l|l|l|l|l|l|l|}
\hline 1995 & 2000 & 2005 & 2006 & 2007 & 2008 & 2009 & 2010 & 2011 & 2012 & 2013 \\
\hline 24.8 & 29.0 & 17.8 & 15.2 & 13.3 & 13.4 & 13.0 & 12.5 & 12.7 & 10.7 & 11.0 \\
\hline
\end{tabular}

Sources: Sotsial'noe polozhenie i uroven' zhizni naseleniya Rossii. 2007: stat. sb. [Social Status and Standard of Living of the Russian Population. 2007: Statistics Digest]. Rosstat [Federal State Statistics Service], Moscow, 2007, p. 144; .Sotsial'noe polozhenie i uroven' zhizni naseleniya Rossii. 2013: stat. sb. [Social Status and Standard of Living of the Russian Population. 2002: Statistics Digest]. Rosstat [Federal State Statistics Service], Moscow, 2013, p. 92; TsBSD [Central Database of Statistical Data]. Rosstat [Federal State Statistics Service]. Available at: http://cbsd.gks.ru/.

the official statistical survey of poverty in Russia. As L.A. Belyaeva points out, despite some disadvantages, the advantages of official statistics include the widespread coverage throughout the country and the uniform methodology and methods of data acquisition ${ }^{15}$. What is more, the collection of information is systematic, thus, the data are comparable and poverty is considered in dynamics.

The Russian state statistics monitor the parameters of poverty, revealing the level, profile and structure. In addition, in recent years the method to study poverty has expanded within the state statistics. It measures not only the incomes and expenses of the poor, but also the resources available to poor households. In this case the monetary and non-monetary revenues to households are taken into account. However, as the article volume is limited, we will analyze the block of indicators that reflect the income of the poor.

As noted earlier, in the absolute poverty concept the poverty line is determined by

${ }^{15}$ Belyaeva L.A. Material'noe neravenstvo v Rossii. Real'nost' i tendentsii [Material Inequality in Russia. Current Situation and Trends]. Sotsiologicheskie issledovaniya [Sociological Studies], 2007, no. 11, p. 30. the minimum set of basic needs and the amount of resources required to meet those needs (the subsistence minimum). In Russia, the absolute poverty line is referred to as the subsistence minimum.

The subsistence minimum sets the size of the income, sufficient to satisfy basic needs at the minimum level. In this regard, we can say that the subsistence minimum characterizes the limited amount of economic resources. Their use ensures a low level of adaptability. While the level of income below the subsistence minimum is an indicator of maladjustment.

According to this content of the subsistence minimum, the population with incomes below the subsistence minimum is considered as the poor. In the official statistics this category is called as the disadvantaged; the population with incomes below the subsistence minimum by two or more times is considered as the extremely poor.

As table 1 shows, the scale of poverty, measured by the share of population with incomes below the subsistence minimum, has decreased by 2.3 times in Russia in 1995-2013. Only the 1998 economic crisis had an adverse impact on these dynamics, 
Table 2. Composition of the poor population by place of residence (based on the sample survey of households' budgets, in \%)

\begin{tabular}{|c|c|c|c|c|c|c|c|c|c|}
\hline \multirow{2}{*}{ Place of residence } & \multicolumn{9}{|c|}{ The disadvantaged } \\
\hline & 2000 & 2005 & 2006 & 2007 & 2008 & 2009 & 2010 & 2011 & 2012 \\
\hline City & 66.0 & 61.4 & 60.8 & 59.6 & 58.0 & 58.1 & 59.8 & 61.2 & 59.6 \\
\hline \multirow[t]{3}{*}{ Village } & 34.0 & 38.6 & 39.2 & 40.4 & 42.0 & 41.9 & 40.2 & 38.8 & 40.4 \\
\hline & \multicolumn{9}{|c|}{ The extremely poor } \\
\hline & $\ldots$ & 48.8 & 46.9 & 45.1 & 44.2 & 42.3 & 45.0 & 49.2 & 55.1 \\
\hline City & $\ldots$ & 51.2 & 53.1 & 54.9 & 55.8 & 57.7 & 55.0 & 50.8 & 44.9 \\
\hline Village & $\ldots$ & 51.2 & 53.1 & 54.9 & 55.8 & 57.7 & 55.0 & 50.8 & 44.9 \\
\hline
\end{tabular}

as the proportion of the poor Russians increased by $4.2 \%$; the trend towards the reduction of absolute poverty remained in subsequent years.

Meanwhile, nowadays the tenth part of the Russians belongs to the poor by the objective parameters of the income amount (see tab. 1). This indicates the need to identify the main sources of poverty and their nature in the modern Russian conditions. In turn, the specific source of poverty (for example, living in certain social conditions or individuals' unwillingness to make efforts to maintain and improve their social status) directly determines the risk of poverty, i.e. the occurrence of the unfavorable outcome for this adaptation subject (adaptant).

To assess the poverty rate it is useful to analyze the dynamics and the state of the main social and demographic characteristics of the poor. We believe that the consideration of the socio-demographic portrait of the disadvantaged and extremely poor population in dynamics will disclose the sustainability of one or another risk of poverty in the modern Russian conditions.
In turn, the characterized features of this portrait as of 2012 reveal key risks of poverty. To estimate the risk of poverty we use the corresponding index applied by the official statistics. The poverty risk index value above 1 shows how many times the poverty risk for the population, grouped according to certain parameters, is higher than the poverty risk for the population as a whole. The index value below 1 indicates the lower poverty risk than the poverty risk for the population as a whole.

As can be seen from table 2, the structure of the poor population by place of residence has not changed significantly: among this category the share of urban population is relatively higher than the proportion of rural population: $59.6 \%$ of the poor live in cities, $40.4 \%$ - in rural settlements. The largest share of the urban population in this category $(28.7 \%$ of the total poor population) lives in small towns with population up to 50 thousand people ${ }^{16}$.

\footnotetext{
${ }^{16}$ Sotsial'noe polozhenie i uroven' zhizni naseleniya Rossii. 2013: stat. sb. [Social Status and Standard of Living of the Russian Population. 2002: Statistics Digest]. Rosstat [Federal State Statistics Service], Moscow, 2013, p. 109.
} 
As for the dynamics of the composition of the extremely poor population (with incomes by two or more times below the subsistence minimum) by place of residence, by 2012 the ratio between urban and rural population changes towards increasing the proportion living in cities, although there was a lower number of the extremely poor among the urban population. As for citizens, in 2012 there was the highest share of the extremely poor in small (with the population being equal to $50-100$ thousand inhabitants and up to 50 thousand people) and medium (100-250 thousand inhabitants) towns ${ }^{17}$.

The poverty risk index value for differently populated settlements shows that this risk increases as far as the type of settlement changes (from rural to urban) and the number of its inhabitants reduces. So, for small towns (with the population being equal to 50-100 thousand inhabitants and up to 50 thousand people) and rural settlements of all types the poverty risk index is above 1 , which means a higher level of poverty risk for the residents of these settlements than for the population as a whole. The poverty risk value is of ${ }^{18} 3.07$ for the residents of rural settlements with population of less than 200 people.

The changes in the composition of the poor population by sex and age group are associated with the increase in the proportion of children under 16 and some reduction in the share of persons of working age and over working age. This trend is

\footnotetext{
17 Ibidem, p. 109.

${ }^{18}$ Ibidem, p. 110.
}

characteristic of both the disadvantaged and the extremely poor population (tab. 3).

Besides, there is a significant gender difference in the category of over working age: the number of women of retirement age is greater than that of men largely due to the increasing disparity between the number of men and women of older ages (see tab. 3). The share of this age group is a bit less among the extremely poor than the disadvantaged due to the alignment of pensions to the subsistence minimum and above.

According to this poverty risk index value, in 2012 the higher poverty risk is typical for children up to 16 (1.48) and young people aged 16-30 (for young men 1.14; for women-1.13) compared to the general population ${ }^{19}$. One of the factors behind this situation is that children and young people live in dependence. At the same time, the increased number of pupils and students of vocational educational institutions leads to the reduction in the number of young people joining the labor market and earning money on their own.

The recent dynamics of the poor population composition in relation to economic activity shows the rise in the proportion of economically active population, including those employed in the economy and the unemployed. In 2012 compared to 2005 there was a greater number of the employed in the economy $(4.8 \%$ of the total poor

${ }^{19}$ Sotsial'noe polozhenie i uroven' zhizni naseleniya Rossii. 2013: stat. sb. [Social Status and Standard of Living of the Russian Population. 2013: Statistics Digest]. Rosstat [Federal State Statistics Service], Moscow, 2013, p. 110. 
Table 3. Composition of the poor population by gender and age groups (based on the sample survey of households' budgets, in \%)

\begin{tabular}{|c|c|c|c|c|c|c|c|c|}
\hline \multirow{2}{*}{ Age group } & \multicolumn{8}{|c|}{ The disadvantaged } \\
\hline & 2005 & 2006 & 2007 & 2008 & 2009 & 2010 & 2011 & 2012 \\
\hline Children under 16 & 21.8 & 21.2 & 21.4 & 22.6 & 23.8 & 25.5 & 26.3 & 27.3 \\
\hline $\begin{array}{l}\text { Working-age population, } \\
\text { including: }\end{array}$ & 65.5 & 65.7 & 65.2 & 64.8 & 64.6 & 64.4 & 63.5 & 62.4 \\
\hline young people aged $16-30$ & 25.6 & 25.6 & 25.3 & 25.6 & 25.6 & 24.9 & 24.2 & 23.4 \\
\hline men aged 31-59 & 18.7 & 19.0 & 18.9 & 18.6 & 18.7 & 19.2 & 19.0 & 19.0 \\
\hline women aged $31-54$ & 21.2 & 21.1 & 21.0 & 20.6 & 20.3 & 20.3 & 20.3 & 20.1 \\
\hline Population over working age, including: & 12.7 & 13.1 & 13.3 & 12.6 & 11.6 & 10.0 & 10.2 & 10.3 \\
\hline men aged 60 and over & 3.5 & 3.6 & 3.8 & 3.5 & 3.1 & 2.5 & 2.7 & 2.7 \\
\hline \multirow[t]{3}{*}{ women aged 55 and over } & 9.1 & 9.5 & 9.6 & 9.1 & 8.6 & 7.5 & 7.5 & 7.6 \\
\hline & \multicolumn{8}{|c|}{ The extremely poor } \\
\hline & 2005 & 2006 & 2007 & 2008 & 2009 & 2010 & 2011 & 2012 \\
\hline Children under 16 & 26.7 & 26.4 & 26.4 & 27.5 & 28.6 & 30.4 & 31.2 & 30.6 \\
\hline $\begin{array}{l}\text { Working-age population, } \\
\text { including: }\end{array}$ & 64.9 & 64.8 & 64.5 & 63.9 & 63.7 & 62.8 & 61.2 & 61.8 \\
\hline young people aged 16--30 & 27.3 & 26.9 & 25.9 & 26.2 & 26.6 & 26.3 & 25.3 & 24.9 \\
\hline men aged $31-59$ & 17.6 & 18.0 & 18.3 & 18.0 & 17.9 & 17.8 & 17.4 & 18.4 \\
\hline women aged 31-54 & 20.0 & 19.9 & 20.2 & 19.7 & 19.1 & 18.7 & 18.5 & 18.5 \\
\hline Population over working age, including: & 8.4 & 8.8 & 9.1 & 8.6 & 7.7 & 6.8 & 7.6 & 7.6 \\
\hline men aged 60 and over & 2.3 & 2.4 & 2.5 & 2.1 & 2.1 & 1.8 & 2.0 & 2.0 \\
\hline women aged 55 and over & 6.1 & 6.3 & 6.6 & 6.5 & 5.6 & 5.0 & 5.6 & 5.6 \\
\hline \multicolumn{9}{|c|}{$\begin{array}{l}\text { Sources: Sotsial'noe polozhenie i uroven' zhizni naseleniya Rossii. 2009: stat. sb. [Social Status and Standard of Living of the Russian } \\
\text { Population. 2009: Statistics Digest]. Rosstat [Federal State Statistics Service], Moscow, 2009, p. 146; Sotsial'noe polozhenie i uroven' } \\
\text { zhizni naseleniya Rossii. 2013: stat. sb. [Social Status and Standard of Living of the Russian Population. 2002: Statistics Digest]. Rosstat } \\
\text { [Federal State Statistics Service], Moscow, 2013, p. } 110 \text {. }\end{array}$} \\
\hline
\end{tabular}

population) and the unemployed (0.4\%) among the disadvantaged. This trend is also characteristic of the extremely poor population (tab. 4).

As for the poverty risk index value by economic activity, in 2012 the high poverty risk compared to the general population can be observed among the unemployed (2.05) and the economically inactive population as a whole ${ }^{20}$ (1.09). Meanwhile, for nonworking pensioners the poverty rate is

\footnotetext{
${ }^{20}$ Ibidem, p. 112.
}

lower (0.72) than for the rest; thus, at a basic level this category is supported by the state guarantees. The authorities conduct monitoring, develop and implement measures to overcome poverty ${ }^{21}$, which ultimately reduces the poverty rate for this social category.

${ }^{21}$ Solov'ev A.K. Problema preodoleniya bednosti pensionerov - klyuchevaya zadacha gosudarstva i obshchestva sovremennoi Rossii [Alleviation of Pensioners' Poverty a Key Task for the State and Society in Contemporary Russia]. Ekonomicheskie i sotsial'nye peremeny: fakty, tendentsii, prognoz [Economic and Social Changes: Facts, Trends, Forecast], 2014, no. 5 (35), pp. 153-155. 
Table 4. Composition of the poor population by economic activity (for persons aged

15 and over, based on the sample survey of the households' budgets, in \%)

\begin{tabular}{|c|c|c|c|c|c|c|c|c|}
\hline & \multicolumn{8}{|c|}{ The disadvantaged } \\
\hline & 2005 & 2006 & 2007 & 2008 & 2009 & 2010 & 2011 & 2012 \\
\hline Economically active population, including: & 60.2 & 60.5 & 61.1 & 61.4 & 63.3 & 64.9 & 65.6 & 65.5 \\
\hline - employed in the economy, of which & 58.4 & 58.7 & 59.4 & 59.7 & 60.7 & 61.0 & 63.1 & 63.2 \\
\hline working pensioners & 3.5 & 3.8 & 4.1 & 4.2 & 4.3 & 3.7 & 4.0 & 4.2 \\
\hline - unemployed & 1.9 & 1.8 & 1.7 & 1.7 & 2.5 & 3.9 & 2.5 & 2.3 \\
\hline Economically inactive population, of which & 39.8 & 39.5 & 38.9 & 38.6 & 36.7 & 35.1 & 34.4 & 34.5 \\
\hline \multirow[t]{3}{*}{ non-working pensioners } & 15.0 & 15.1 & 15.1 & 14.3 & 12.7 & 11.9 & 11.6 & 11.7 \\
\hline & \multicolumn{8}{|c|}{ The extremely poor } \\
\hline & 2005 & 2006 & 2007 & 2008 & 2009 & 2010 & 2011 & 2012 \\
\hline Economically active population, including: & 57.9 & 58.3 & 57.5 & 57.4 & 59.5 & 61.8 & 61.4 & 63.3 \\
\hline - employed in the economy, of which & 54.8 & 55.1 & 54.5 & 54.3 & 54.9 & 56.4 & 58.1 & 60.3 \\
\hline working pensioners & 2.5 & 2.6 & 2.7 & 2.6 & 3.3 & 2.8 & 3.4 & 3.3 \\
\hline - unemployed & 3.2 & 3.2 & 3.1 & 3.1 & 4.6 & 5.4 & 3.3 & 3.0 \\
\hline Economically inactive population, of which & 42.1 & 41.7 & 42.5 & 42.6 & 40.5 & 38.2 & 38.6 & 36.7 \\
\hline non-working pensioners & 11.2 & 11.4 & 11.7 & 11.4 & 9.2 & 8.5 & 9.2 & 9.1 \\
\hline
\end{tabular}

The poverty rate for persons employed in the economy amounted to ${ }^{22} 0.8$ in 2012 ; it indicates a lower level of poverty risk relative to the rest of the population. However, the small interval between this value and 1 makes the problem of the working poor. In other words, in terms of socio-economic adaptation to modern Russian conditions the employment and the working age are not self-sufficient adaptation resources. In this respect it is necessary to pay attention to other characteristics of the workforce that ensure successful adaptation to socio-economic changes, particularly the dependence of

${ }^{22}$ Sotsial'noe polozhenie i uroven' zhizni naseleniya Rossii. 2013: stat. sb. [Social Status and Standard of Living of the Russian Population. 2013: Statistics Digest]. Rosstat [Federal State Statistics Service], Moscow, 2013, p. 112. incomes of the employed in the economy on the economic activity, the form of ownership of the enterprise and the level of education.

According to the sample survey of enterprises, in 2013 the largest share of workers with low wages (up to 7,400 rubles) is concentrated in agriculture, hunting and forestry $(19.3 \%$ of the number of people employed in this sector). The number of the employed in this type of economic activity with wages up to 5,000 rubles comprised $3.1 \%$ of all employed in this economy sector, in the range of 5,000-5,800 rubles $6.2 \%, 5,800-7,400$ rubles $-10 \%$. Similar situation is also observed in the sphere of education, health care and social services ${ }^{23}$.

\footnotetext{
${ }^{23}$ Ibidem, p. 99.
} 
Table 5. Composition of the poor population in relation to economic activity and by educational level in 2012 (for persons aged 15 years and over, based on a sample survey of households" budgets, in \%)

\begin{tabular}{|c|c|c|c|c|c|c|c|c|c|c|}
\hline & \multirow[b]{2}{*}{ 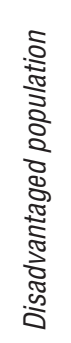 } & \multicolumn{5}{|c|}{ Vocational education level } & \multicolumn{4}{|c|}{ General education level } \\
\hline & & 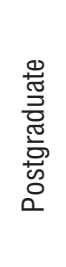 & 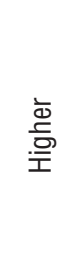 & 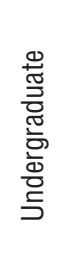 & 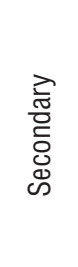 & 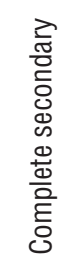 & $\begin{array}{l}\overline{\frac{\pi}{\pi}} \\
\bar{\varpi} \\
\bar{J}\end{array}$ & $\frac{.0}{\mathscr{D}}$ & 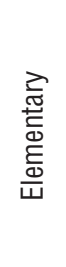 & 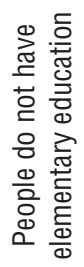 \\
\hline $\begin{array}{l}\text { Economically active } \\
\text { population, including: }\end{array}$ & 100 & 0.1 & 21.4 & 2.4 & 36.0 & 15.8 & 19.8 & 4.3 & 0.2 & 0.0 \\
\hline employed in the economy & 100 & 0.1 & 21.8 & 2.4 & 36.3 & 15.8 & 19.3 & 4.0 & 0.2 & 0.0 \\
\hline unemployed & 100 & 0.0 & 11.3 & 0.7 & 25.2 & 16.2 & 34.7 & 10.8 & 1.0 & 0.0 \\
\hline $\begin{array}{l}\text { Economically inactive } \\
\text { population }\end{array}$ & 100 & 0.0 & 6.9 & 2.6 & 18.5 & 9.5 & 28.7 & 24.1 & 8.5 & 1.2 \\
\hline
\end{tabular}

According to the same survey, in 2013 there was a greater number of employees earning up to 5,000 rubles at state and municipal organizations ( $1.3 \%$ of all employed in such organizations) than at non-state enterprises $(0.7 \%)$. In general, about $1 / 10$ of the number of employees at state and municipal organizations (10.8\%) got low salary (up to 7,400 rubles). The number of employees with this level of salary is two times lower at non-state organizations $(4.7 \%)^{24}$.

Table 5 shows that more than half of the poor, employed in the economy, have professional education: $21.8 \%$ - higher, $36.3 \%$ - secondary. Considering the above facts, we can identify a greater dependence of wages on the type of economic activity and the form of ownership of the enterprise than the level of education.

\footnotetext{
${ }^{24}$ Ibidem, p. 101.
}

However, there is a small number of those with vocational education among the unemployed and the economically inactive population included in the category of poor people.

If we consider the poverty risk index value in terms of the level of education in 2012, the risk of poverty is lower for persons with secondary vocational and higher education, than for the general population. At the same time, the higher the level of professional education, the lower the rate of poverty: it amounts to 0.87 for persons with secondary vocational; 0.82 - undergraduate; 0.48 higher; 0.31 - postgraduate professional education. At the same time, the poverty rate is almost by half higher for the population with basic general education (1.51), primary education (1.44) and no education (1.47) than for the total population ${ }^{25}$.

\footnotetext{
25 Ibidem, p. 112.
} 
Thus, the analysis of the dynamics and the state of objective sources of poverty, the high poverty rates are registered in small towns (with the population being equal to $50-100$ thousand inhabitants and up to 50 thousand people), refer to children and young people under 30 , the unemployed and economically inactive population. Besides, the working poor employed in industries get low wages.

The scientific and practical significance of the study stems from the fact that, on the one hand, the results of the analysis help generate scientific understanding of the dynamics and the state of the main characteristics of poverty in the modern Russia: the level and the socio-demographic composition of the poor and the key risks of poverty of socio-demographic nature.

The analysis of statistical indicators of poverty can be supplemented by their comparison with the results of subjective poverty measurement to make the picture of poverty risks in the modern Russian conditions more vivid.

On the other hand, the findings can be used to determine the main directions and measures to reduce poverty and its risks as part of the development and implementation of social policies.

As noted by N.M. Rimashevskaya, the selection of effective measures to reduce poverty requires the data on the sociodemographic composition of poverty and its dynamics.

The indicators characterizing the change in the structure of the poor popu- lation reflect the directions and methods to solve the problem ${ }^{26}$.

In our view, the issues of poverty risk give another look at the key directions to decrease poverty in the contemporary Russian society. The attention should be drawn both to the measures for poverty reduction and poverty prevention, aimed at improving the adaptive capacity of people exposed to high risks of poverty. Thus, it is necessary to decrease poverty rates and strengthen adaptive capacities of the population living in small towns and rural settlements, children and young people, the unemployed, economically inactive population and low-income workers.

Moreover, one should take into account the relationship between the key poverty risk concentration areas: poverty of the population in small towns and rural areas and unemployment, child poverty and working-age population poverty. So, in most cases child poverty is largely a consequence of the problem of the working poor and, in fact, is a problem of families with children whose parents have low incomes.

Therefore, the reduction of child poverty depends on the solution of problems on the labor market - decrease in the prevalence of low-income employment and unemployment and increase in the efficiency of social programs to provide targeted support to families with children (benefits, maternity capital, etc.).

\footnotetext{
${ }^{26}$ Rimashevskaya, N.M. Bednost' i marginalizatsiya naseleniya [Poverty and Marginalization of the Population]. Sotsiologicheskie issledovaniya [Sociological Studies], 2004, no. 4, pp. 36-38.
} 
Given the relationship of the poverty sources, it can be stated that the mechanism to realize the poverty reduction policy should include the consistent implementation of the following measures:

1. In terms of the reallocation of labor forces and the betterment of employment:

- restructuring of the economy and the employment, development of the institutional environment to use market-based incentives promoting employment on the regional labor markets, creation of the conditions for the expansion of selfemployment and entrepreneurial initiative (improvement of the credit system, access to material infrastructure, etc.);

- identification of the sectoral and regional priorities in the development and preservation of jobs, facilitation of the reallocation of workers and optimization of the use of labor potential, promotion of the social mobility, including through interregional and intra-regional migration;

- identification of the economical requirements in personnel with specific skills, enhancement of the system of training and retraining of workers and the unemployed, encouragement of the professional education competitiveness.

2. In terms of the reduction in the number of low-wage workers:

- improvement of the labor efficiency and expansion of the opportunities for further employment;
- increase in the minimum wage and introduction of the smooth wage indexation mechanism.

3. In terms of the enhancement of the system to protect socially vulnerable layers of the population:

- better targeting of social benefits and benefits to the poor, refusal to provide assistance to the non-poor population, greater social payments to the poor;

- strengthening control over social assistance provision.

The economic crisis is characterized by the increased risks of unemployment, underemployment, reduction in the level of income and consumption. Current poverty can transfer to chronic, accompanied by the changes in labor motivation, the distribution of a welfare mentality. In this case the system of anti-crisis measures should include activities aimed at reducing poverty rates and enhancing the population's resources. It is advisable to apply and develop the practice of individual adaptation programs for the able-bodied population. They prohibit the individual to combine informal employment and social benefits, encourage the unemployed to find a job, exploit the working population's capacities in order to use and build their labor, educational and professional potential (education, training and retraining). The development and implementation of such programs can be effected by placement services.

\section{References}

1. Bednost' $i$ bednye $v$ sovremennoi Rossii [Poverty and the Poor in Modern Russia]. Under editorship of M.K. Gorshkov i N.E. Tikhonova. Moscow: Ves' Mir, 2014. 304 p. 
2. Belyaeva L.A. Material'noe neravenstvo v Rossii. Real'nost' i tendentsii [Material Inequality in Russia. Current Situation and Trends]. Sotsiologicheskie issledovaniya [Sociological Studies], 2007, no. 11, pp. 29-41.

3. Belyaeva L.A. Sotsial'naya stratifikatsiya i bednost' v regionakh Rossii (k sostavleniyu sotsiokul'turnogo portreta regionov) [Social Stratification and Poverty in the Regions of Russia (to Build a Socio-Cultural Portrait of the Regions)]. Sotsiologicheskie issledovaniya [Sociological Studies], 2006, no. 9, pp. 52-63.

4. Zubarevich N.V. Sotsial'noe razvitie regionov Rossii: problemy $i$ tendentsii perekhodnogo perioda [Social Development of Russian Regions: Problems and Tendencies of the Transition Period]. Second edition. Moscow: Editorial URSS, 2005.

5. Lapin N.I., Belyaeva L.A. Programma i tipovoi instrumentarii "Sotsiokul'turnyi portret regiona Rossii" (Modifikatsiya - 2010) [Program and Standard Tool "Socio-Cultural Portrait of the Region of Russia" (Modification - 2010]. Ros. akad. nauk, In-t filosofii. Moscow: IFRAN, 2010. $111 \mathrm{p}$.

6. Litvinov V.A. Prozhitochnyi minimum: istoriya, metodika, analiz [Minimum Wage: History, Method, Analysis]. Moscow: KomKniga, 2006. 280 p.

7. Ovcharova L.N. Teoreticheskie i prakticheskie podkhody $k$ otsenke urovnya, profilya $i$ faktorov bednosti: rossiiskii i mezhdunarodnyi opyt [Theoretical and Practical Approaches to the Assessment of the Level, Profile and Determinants of Poverty: Russian and International Experience]. Moscow: M-Studio, 2009. 268 p.

8. Partisipatornyi podkhod $v$ povyshenii kachestva zhizni naseleniya: monografiya [Participatory Approach to Improving the Quality of Life of the Population: Monograph]. Under general editorship of N.M. Rimashevskaya, N.N. Ivashinenko. Nizhny Novgorod - Moscow: Izd-vo Nizhegorodskogo gosuniversiteta, 2013. 268 p.

9. Pasovets Yu.M. Imushchestvennaya stratifikatsiya naseleniya Rossii i ee regionov [Property Stratification of the Population of Russia and Its Regions]. Regionologiya [Regionology], 2011, vol. 77, no. 4, pp. 202-210.

10. Pasovets Yu.M. Sotsial'nye resursy i ogranicheniya razvitiya regiona v kontekste obshcherossiiskikh izmenenii [Social Resources and Limitations of the Region's Development in the Context of Nationwide Changes]. Kursk: Kurskii gos. un-t., 2010. 151 p.

11. Rimashevskaya, N.M. Bednost' i marginalizatsiya naseleniya [Poverty and Marginalization of the Population]. Sotsiologicheskie issledovaniya [Sociological Studies], 2004, no. 4, pp. 33-43.

12. Slobodenyuk E.D., Tikhonova N.E. Evristicheskie vozmozhnosti absolyutnogo i otnositel'nogo podkhodov k izucheniyu bednosti v rossiiskikh usloviyakh [Heuristic Possibilities of Absolute and Relative Approaches to the Study of Poverty in Russia]. Sotsiologiya: 4M [Sociology: 4M], 2011, no. 33, pp. 5-27.

13. Solov'ev A.K. Problema preodoleniya bednosti pensionerov - klyuchevaya zadacha gosudarstva i obshchestva sovremennoi Rossii [Alleviation of Pensioners' Poverty - a Key Task for the State and Society in Contemporary Russia]. Ekonomicheskie $i$ sotsial'nye peremeny: fakty, tendentsii, prognoz [Economic and Social Changes: Facts, Trends, Forecast], 2014, no. 5 (35), pp. 143-155.

14. Sotsial'noe polozhenie i uroven' zhizni naseleniya Rossii. 2002: stat. sb. [Social Status and Standard of Living of the Russian Population. 2002: Statistics Digest]. Goskomstat Rossii [Federal State Statistics Service], Moscow, 2002.

15. Sotsial'noe polozhenie i uroven' zhizni naseleniya Rossii. 2007: stat. sb. [Social Status and Standard of Living of the Russian Population. 2007: Statistics Digest]. Rosstat [Federal State Statistics Service], Moscow, 2007.

16. Sotsial'noe polozhenie i uroven' zhizni naseleniya Rossii. 2009: stat. sb. [Social Status and Standard of Living of the Russian Population. 2009: Statistics Digest]. Rosstat [Federal State Statistics Service], Moscow, 2009.

17. Sotsial'noe polozhenie i uroven' zhizni naseleniya Rossii. 2013: stat. sb. [Social Status and Standard of Living of the Russian Population. 2013: Statistics Digest]. Rosstat [Federal State Statistics Service], Moscow, 2013.

18. Tikhonova, N.E. Fenomen bednosti v sovremennoi Rossii [Phenomenon of Poverty in Modern Russia]. Sotsiologicheskie issledovaniya [Sociological Studies], 2014, no. 1, pp. 7-19.

19. Federal'nyi zakon "O prozhitochnom minimume v Rossiiskoi Federatsii”: ot 24.10.1997 g. (s izm.) [Federal Law "On Subsistence Minimum in the Russian Federation of October 24, 1997 (with Amendments)]. Konsul'tantPlyus [Reference-Legal System KonsultantPlus]. 
20. TsBSD [Central Database of Statistical Data]. Rosstat [Federal State Statistics Service]. Available at: http://cbsd.gks.ru/.

21. Shabunova A.A., Lastochkina M.A. Preodolenie sotsial'nogo neravenstva kak impul's k sotsiokul'turnoi modernizatsii [Overcoming Social Inequality as an Impetus to Socio-Cultural Modernization]. Ekonomicheskie i sotsial'nye peremeny: fakty, tendentsii, prognoz [Economic and Social Changes: Facts, Trends, Forecast], 2014, no. 3 (33), pp. 69-83. - DOI: 10.15838/esc/2014.3.33.6

\section{Cited works}

1. Poverty and the Poor in Modern Russia. Under editorship of M.K. Gorshkov i N.E. Tikhonova. Moscow: Ves' Mir, 2014. 304 p.

2. Belyaeva L.A. Material Inequality in Russia. Current Situation and Trends. Sociological Studies, 2007, no. 11, pp. 29-41.

3. Belyaeva L.A. Social Stratification and Poverty in the Regions of Russia (to Build a Socio-Cultural Portrait of the Regions). Sociological Studies, 2006, no. 9, pp. 52-63.

4. Zubarevich N.V. Social Development of Russian Regions: Problems and Tendencies of the Transition Period. Second edition. Moscow: Editorial URSS, 2005.

5. Lapin N.I., Belyaeva L.A. Program and Standard Tool "Socio-Cultural Portrait of the Region of Russia" (Modification - 2010. Ros. akad. nauk, In-t filosofii. Moscow: IFRAN, 2010. 111 p.

6. Litvinov V.A. Minimum Wage: History, Method, Analysis. Moscow: KomKniga, 2006. 280 p.

7. Ovcharova L.N. Theoretical and Practical Approaches to the Assessment of the Level, Profile and Determinants of Poverty: Russian and International Experience. Moscow: M-Studio, 2009. 268 p.

8. Participatory Approach to Improving the Quality of Life of the Population: Monograph. Under general editorship of N.M. Rimashevskaya, N.N. Ivashinenko. Nizhny Novgorod - Moscow: Izd-vo Nizhegorodskogo gosuniversiteta, 2013. 268 p.

9. Pasovets Yu.M. Property Stratification of the Population of Russia and Its Regions. Regionology, 2011, vol. 77, no. 4, pp. 202-210.

10. Pasovets Yu.M. Social Resources and Limitations of the Region's Development in the Context of Nationwide Changes. Kursk: Kurskii gos. un-t., 2010. 151 p.

11. Rimashevskaya, N.M. Poverty and Marginalization of the Population. Sociological Studies, 2004, no. 4, pp. 33-43.

12. Slobodenyuk E.D., Tikhonova N.E. Heuristic Possibilities of Absolute and Relative Approaches to the Study of Poverty in Russia. Sociology: 4M, 2011, no. 33, pp. 5-27.

13. Solov'ev A.K. Alleviation of Pensioners' Poverty - a Key Task for the state and Society in Contemporary Russia. Economic and Social Changes: Facts, Trends, Forecast, 2014, no. 5 (35), pp. 143-155.

14. Social Status and Standard of Living of the Russian Population. 2002: Statistics Digest. Federal State Statistics Service, Moscow, 2002.

15. Social Status and Standard of Living of the Russian Population. 2007: Statistics Digest. Federal State Statistics Service, Moscow, 2007.

16. Social Status and Standard of Living of the Russian Population. 2009: Statistics Digest. Federal State Statistics Service, Moscow, 2009.

17. Social Status and Standard of Living of the Russian Population. 2002: Statistics Digest. Federal State Statistics Service, Moscow, 2013.

18. Tikhonova N.E. Phenomenon of Poverty in Modern Russia. Sociological Studies, 2014, no. 1, pp. 7-19.

19. Federal Law “On Subsistence Minimum in the Russian Federation of October 24, 1997 (with Amendments). Reference-Legal System KonsultantPlus.

20. Central Database of Statistical Data. Federal State Statistics Service. Available at: http://cbsd.gks.ru/.

21. Shabunova A.A., Lastochkina M.A. Overcoming Social Inequality as an Impetus to Socio-Cultural Modernization. Economic and Social Changes: Facts, Trends, Forecast, 2014, no. 3 (33), pp. 69-83. 